\title{
The Morphology of the Ovule and Female Flower of Juglans regia and of a few allied Genera.
}

\author{
BY \\ M. BENSON, D.Sc., F.L.S. \\ AND \\ E. J. WELSFORD, F.L.S. \\ With eight Figures in the Text.
}

THE morphology of the walnut was worked out by Van Tieghem as 1 long ago as 1869 but his results were unfortunately published without any figures. ${ }^{1}$ In I 9,05 appeared an account by Nicoloff, ${ }^{2}$ differing in many important points from that of Van Tieghem. Numerous figures were given but they do not demonstrate the points on which he differs from Van Tieghem. We determined therefore to investigate this problem and can now state that our results confirm in all particulars those of Van Tieghem. Nicoloff, though ostensibly working out the placentation of the ovule, has not once figured the dorsal bundles of the carpellary leaves. He insists that the placental bundles are a direct continuation of those of the stem but does not figure them in continuity with the bundles of the stem. We have been able to show that they are part of the carpellary leaf-traces and that hence the ovule is appendicular.

Those who wish to clearly understand the structure should consult Van Tieghem's paper. We only propose to state so much of our results as will render the diagrams intelligible and bring the facts elicited by Van Tieghem and others into relation with more modern views on the nature of the Angiospermic flower.

\section{JUGLANS REGIA.}

The female flower of Fuglans regia is generally composed of 2-3 carpels surrounded by four green 'perianth' leaves, distichously arranged, and a cupule constructed probably of the subtending bract and two lateral bracteoles. All these nine leaves are connate in such a way that only their

1 Van Tieghem, Anatomie de la fleur femelle du noyer. Bull. Soc. Bot., t. xvi, p. $4^{12}$.

${ }^{2}$ Nicoloff, Sur le type floral etc. des Juglandées. Journ, de Bot., t. xxviii, xxix.

[Annals of Botany, Vol. XXIII. No. XCII, October, I909.] 

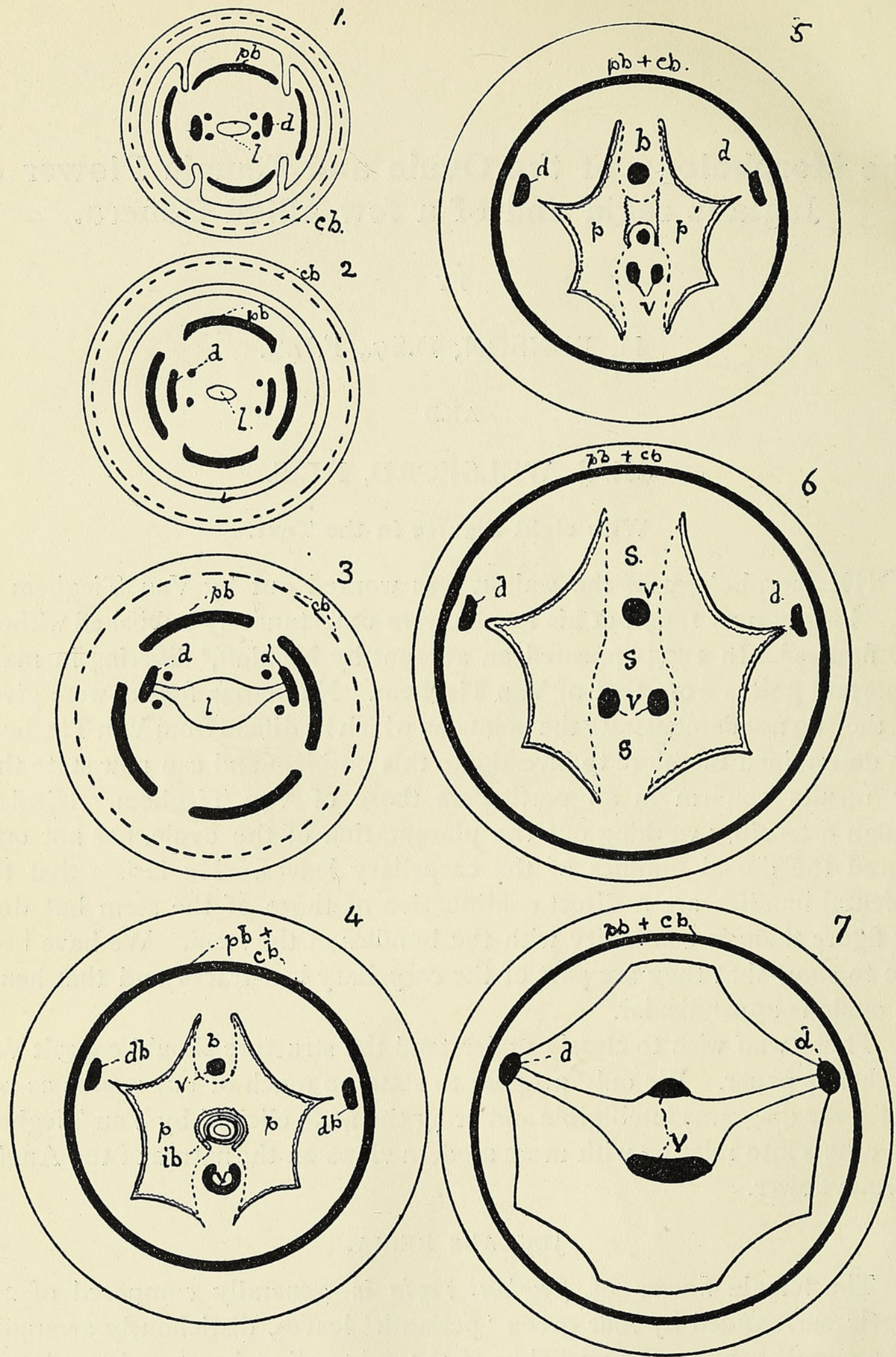

TEXT-FIG. I. I-7. Juglans regia. Seven diagrams of transverse sections through the female flower. I. In region near apex where the cupule and perianth are becoming free. 2. The cupule rim is still free, but the four perianth leaves are adherent to the ovary. 3-7 show the greater development of one carpel with its fertile placenta.

$b=$ barren placenta. $c b=$ cupule bundles. $d=$ dorsal bundles of carpel. $i b=$ integumentary bundle. $l=$ loculus. $p=$ packing tissue. $\quad p b=$ perianth bundles. $s=$ septum. $\quad v=$ ventral bundle of carpel or placental bundle. 
upper portions are free. The bract varies in the degree of adhesion, the cupule shows only a free rim and the perianth four free tips surrounding the two- or three-lobed styles. Nevertheless the vascular supply for each of the leaves is given off from the stem stele at the base of the flower, which, as Van Tieghem points out, is erroneously called 'an inferior ovary'. These leaf bundles are entered in Text-fig. I. I-3, but in the other figures of Fuglans, Text-figs. I. 4-7, III, and IV, the outer bundles are merely represented by a single line, since it is with the gynoecium we are mainly concerned.

\section{Gynoecium.}

The trimerous condition is relatively rare but interesting as showing a resemblance with the gynoecia of the Fagaceae.
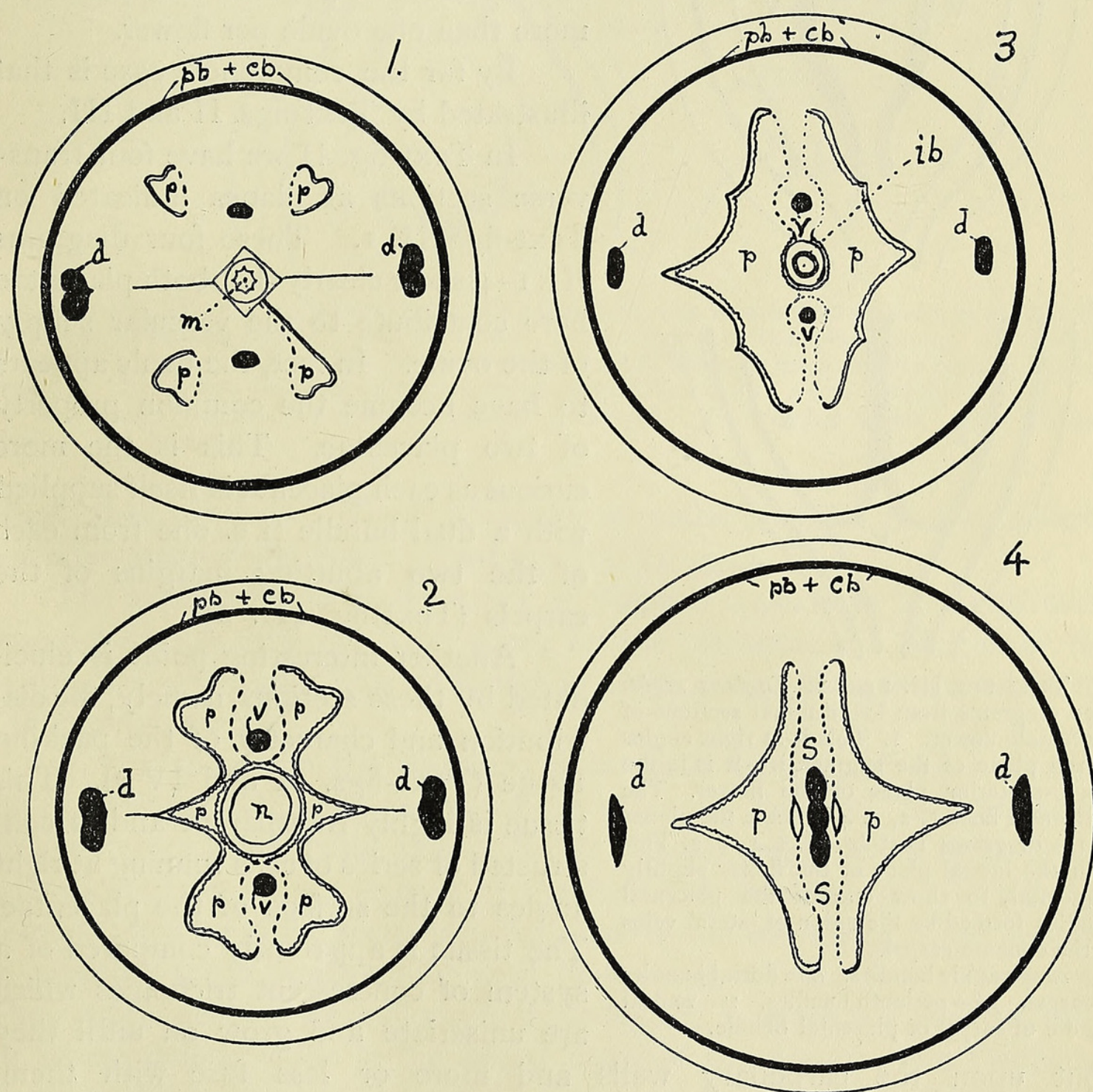

TEXT-FIG. II. I-4. Juglans regia. Four diagrams from transverse sections in the planes indicated on Text-fig. III. I. These represent the ordinary case in which both placentae contribute to the support of the single ovule.

$c b=$ cupule bundles. $d=$ dorsal bundles of carpel. $i b=$ integumentary bundle. $m=$ micropyle. $n=$ nucellus. $p=$ packing tissue. $p b=$ perianth bundles. $s=$ septum. $v=$ ventral bundle of carpel or placental bundle. 
By far the commoner condition is that of dimery. In such flowers both Van Tieghem and ourselves have found that the placentation may be obviously parietal. Diagrams from some of the sections of a complete transverse series are given in Text-fig. I. The two dorsal bundles which run
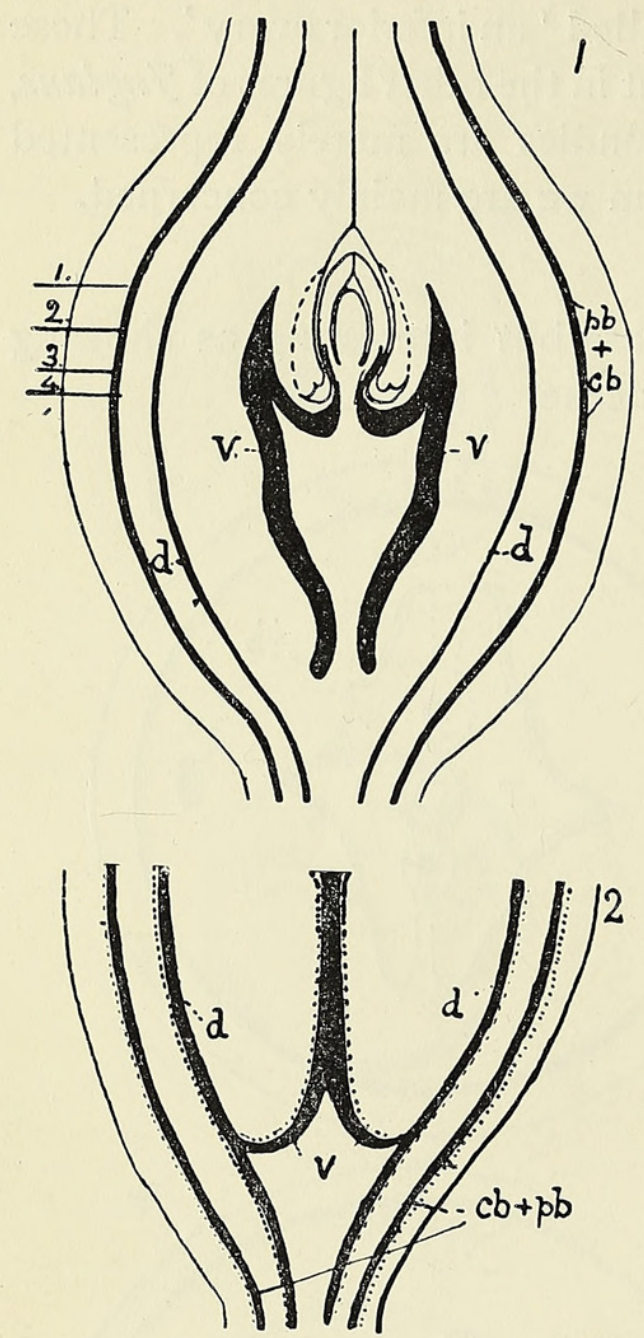

TEXT-FIG. III. I and 2. Juglans regia. Two diagrams from longitudinal sections of the female flower. I. This is at right angles to the plane of the stigmas, i.e. it is in the antero-posterior plane of the flower. The horizontal lines I, 2, 3, 4 indicate the planes of the diagrams Text-fig. II. J-4. 2. This is in the lateral plane of the flower slightly tangential, to show one of the placental bundles formed by the union of lateral veins of the connate carpels.

$c b=$ cupule bundles. $d=$ dorsal bundles of carpel. $p b=$ perianth bundles. $v=$ ventral bundle of carpel or placental bundle. straight up into the styles are obliquely placed and the placental bundles $(v)$ are of unequal size. It is seen that only one placenta (i. e. the larger) bears an ovule (Text-fig. I. 4-5), the other is barren. Van Tieghem points out that the existence of a barren placenta indicates that the ancestors of Fuglans had produced more than one ovule per flower.

By far the commonest case is that illustrated by Text-figs. II and III.

In Text-fig. II we have four transverse sections at planes indicated on Text-fig. III. I. These four diagrams (II. I-4) show clearly that both placentae here contribute to the vascular supply of the ovule. In fact, the ovule appears to have become the common property of two placentae. This is the more curious as each placenta is itself supplied with a dual bundle (i.e. one from each of the two abutting margins of the carpels (Text-fig. III. 2).

Another interesting point is elucidated by these sections, namely, the distribution and character of the packing tissue (Text-figs. II and IV p). This tissue is highly transparent and is constructed of series of cells running at right angles to the surface of the placentae. The tissue is apparently composed of a system of concrescent trichomes which are uniseriate and grow on until they abut upon the carpellary walls and more or less fuse with them. Nawaschin ${ }^{1}$ describes it as follows :- ' Dieselbe füllt die ganze Fruchtknotenhöhlung so vollständig aus, dass die Oberfläche der Placenta und die Fruchtknotenwandung sich gegenseitig beruhren und sogar stellenweise mit einander verschmelzen.'

1 Nawaschin, Ein neues Beispiel der Chalazogamie. Bot. Centralbl., I895. 
It is through this tissue that he succeeded in showing that the pollentube made its way to the chalaza of the ovule.

The upwardly running series of cells of this packing tissue are those referred to by E. M. Kershaw ${ }^{1}$ as ' an obturator'. In all the specimens we have seen they are so closely attached to the ovarian wall that they appear as represented in Text-fig. IV. I and 2.

They are attached to the middle region of the low septum made by the junction of the two placentae, and are seen in transverse section in Textfig. II. 2.

Their form and height in longtitudinal sections depend on the plane in

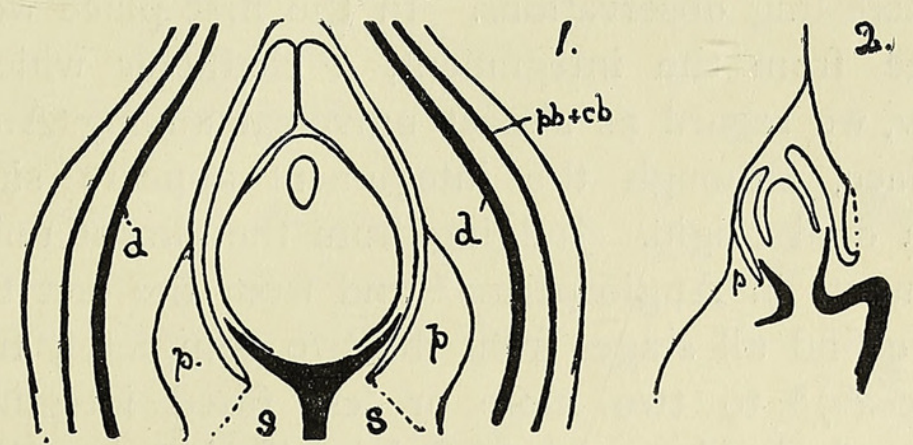

TeXT-FIG. IV. I, 2. Juglans regia. Two diagrams rom longitudinal sections to explain the relation of the packing tissue $(p)$ and the ovule. I. Lies in the median plane through the midribs of the two carpels. 2. Is oblique, to illustrate the limited extent of the upwardly running packing tissue $(p)$. These two diagrams should be compared with Text-fig. II. 2 and Text-fig. III. I.

$c b=$ cupule bundles. $d=$ dorsal bundles of carpel. $p=$ packing tissue. $p b=$ perianth bundles. $s=$ septum.

which they are cut. They disappear in radial sections in the anteroposterior plane of the flower (Text-fig. III. I).

The packing tissue in the ovary of Fuglans appears to be comparable morphologically with the hairs borne on the placentae and funicles of the ovules of Populus and Salix, although in these genera the growth subserves a different function.

If we turn now to the diagrams from radial sections of the flower we see in Text-fig. III. 2 the source of the placental bundles. They have no direct representatives in the axis, as Nicoloff claims, but are built up from the leaf-traces given off at the base of the flower to the carpels. This fact is demonstrated by radial sections in the plane of the two styles. The bundles in question travel horizontally until they reach the centre of the flower. Their subsequent course is shown in Text-fig. III. $I$, which is a diagram from an almost radial section in the lateral plane of the flower. Van Tieghem ${ }^{2}$ explains this course as follows :- ' Le faisceau descendant destiné à l'ovule forme d'abord un assez long funicule qui demeure compris dans le parenchyme du bord fertile.' He thus claims that not only is the ovule

1 E. M. Kershaw, Annals of Botany, April, 1909, p. 337.

2 Van Tieghem, loc. cit. 
appendicular but parietal and anatropous. With this conclusion we entirely concur-even though for purely descriptive purposes it may be convenient to call it basal and orthotropous.

Possibly if we knew more of the phylogenetic history of the basal ovule in other families it might be equally clearly demonstrated that it admitted of the same interpretation.

\section{The Ovule.}

The placentation has already been dealt with in the previous paragraph. We wish now to discuss the integumentary structures, as they somewhat resemble those of Myrica Gale, on which E. M. Kershaw ${ }^{1}$ has made some interesting observations. In the first place we note that the nucellus is free from the integument, a character which, contrary to E. M. Kershaw, we regard as almost universal among Angiosperms. In the second place, although the integument appears single, there are indications of a dual origin. Judging from the almost universal presence of two integuments in Angiosperms ${ }^{2}$ and from the fact that among the Amentiferae we find all stages from the two completely free integuments (e.g. in Fagaceae) ${ }^{3}$ to two more or less fused integuments (e.g. in Casuarinaceae and Corylaceae) ${ }^{4}$ we feel justified in regarding the ovule of Fuglans as bitegumentary. The integuments are however very nearly completely merged.

\section{Vascular Supply of the Ovule.}

Van Tieghem ${ }^{5}$ not only accepts the dual nature of the integument but makes the following statement with respect to the distribution of the vascular supply :- ' Parvenu sous la base du corps de l'ovule, ce faisceau pénètre dans la membrane externe sans envoyer aucune branche à la membrane interne ; le siège exclusif, en profondeur, du système vasculaire du corps de l'ovule est donc la membrane externe.'

As in Myrica Gale, the placental strand on entering the ovule of Fuglans gives rise to a number of bundles which lie symmetrically about the ovule, but the number is much larger than in Myrica. The number is approximately twenty and they appear to be as numerous in the rarer case where only one placenta feeds the ovule as where two placentae contribute.

\section{Crenate Form of Transverse Section of Micropyle.}

This phenomenon, which is not uncommon among the more primitive Angiospermic ovules, e.g. Rheum, reaches a remarkable development in Fuglans regia. It occurs in young ovules before fertilization and is well

${ }^{1}$ E. M. Kershaw, The Structure and Development of the Ovule of Myrica Gale. Annals of Botany, 1909, p. 357

2 V. Payer, Organogénie de la fleur (undique).

${ }^{3}$ Benson, Contribution to the Embryology of the Amentiferae, part i, Trans. Linn. Soc., I 894.

4 Benson, Sanday, Berridge, Contribution to the Embryology of the Amentiferae, part ii, Trans. Linn. Soc., 1905 , pp. 68 and 69 , pp. 48 , Plate 6.

${ }^{5}$ Van Tieghem, loc. cit., pp. 4I 5-16. 
marked, while the peripheral outline is strictly circular. This is shown in Text-fig. II. I.

It is tempting but probably at present unsafe to see in this structure a vestige of the canopy which is so universally present in the 'Lagenostoma' series of Palaeozoic ovules and persists clearly in Bennettites Morierei.

\section{Summary of results in Fulgans regia.}

x. The female flowers of Fulgans regia exhibit interesting phases of reduction as follows:-

(a) The origin of a dimerous condition from a trimerous.

(b) Barren placentae with a vascular supply.

(c) One mode of the phylogenetic origin of the orthotropous basal ovule from an anatropous, parietal type.

2. The above explanation of the female flower of Fuglans tends to reduce the importance of the divergent characters of Juglandaceae and Salicaceae. We refer to the following characters :-

(a) The non-contribution of the axis to the ovary.

(b) The presence of packing tissue originating from the funicle and placenta.

(c) The parietal placentation of the anatropous ovule.

\section{Myrica GALE.}

As the account given by E. M. Kershaw ${ }^{1}$ of the vascular supply of the socalled 'basal' ovule of Myrica Gale did not appear to us in harmony with the view that it was appendicular, we have made a careful investigation of the vas-
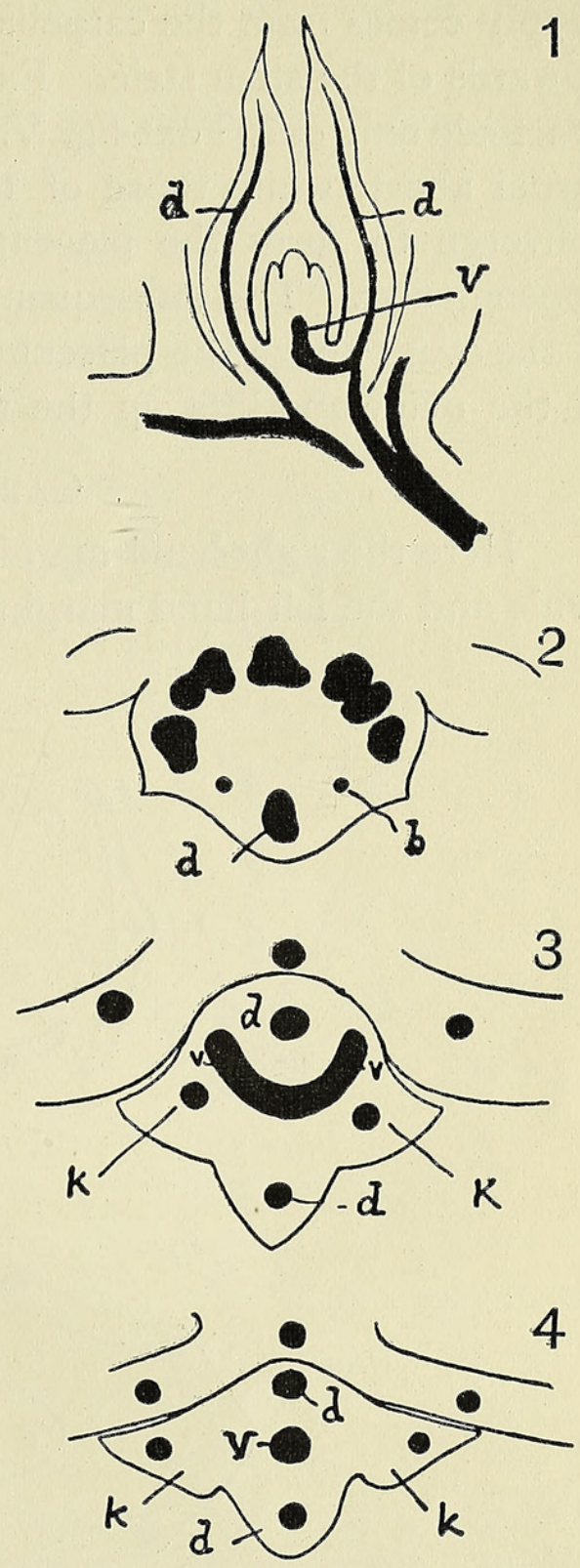

TeXT-Fig. V. I-4. Myrica Gale. Four diagrams, of which $\mathrm{I}$ is from a longitudinal section in the antero-posterior plane. This shows the origin of the placental bundle from the anterior carpel. 2-4 are obliquely transverse to the peduncle. They show the region where the traces to all the floral leaves are given off. The lateral strands of the barren carpel which can be seen in $2 b$ soon die out, but those of the anterior fertile carpel converge $(3 v)$ and form the placental strand $(4 v)$.

$b=$ barren placenta. $d=$ dorsal bundles of carpel. $k=$ bracteole. $v=$ ventral bundle of carpel or placental bundle. cular supply of the whole flower, both in transverse and longitudinal micro- 
tome series. E. M. Kershaw ${ }^{1}$ appears to have overlooked the sections in the planes of Text-fig. V. I-3, which show clearly that the placental supply comes from the carpellary leaf-trace and is not a direct continuation upwards of the stem stele. Each carpel receives a triple leaf-trace but each bracteole only one, Text-fig. V. 2, 3. The two lateral veins of the posterior carpel abort, while those of the anterior carpel are well developed and converge to form the placental supply. We thus regard the ovule as appendicular. The subsequent intercalary development of the outer walls of the ovary above the placenta gives rise to the appearance of basal origin in the ovule and lifts up the two bracteoles like wings.

\section{Carpinus Betulus.}

Here the right-hand margin of one carpel supplies the strand for one ovule and the left-hand margin of the other carpel the other ovule. These
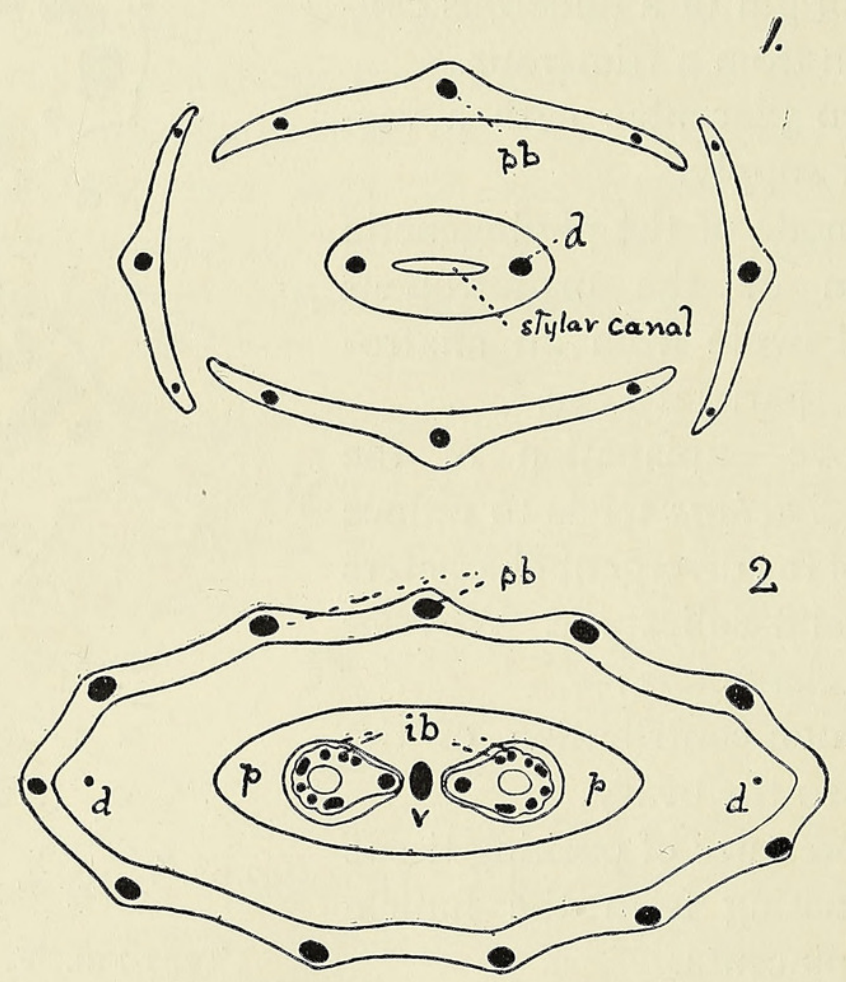

TEXT-FIg. VI. I and 2. Carpinus Betulus. Two diagrams from transverse sections of the female flower. I shows the four distichously arranged perianth leaves now free. 2 shows them united with ovary. The dorsal bundles of the two carpels are very small. Here may be seen the bundles of the outer integuments, $i b$.

$d=$ dorsal bundles of carpel. $i b=$ integumentary bundle. $p=$ packing tissue. $p b=$ perianth bundles. $v=$ ventral bundle of carpel or placental bundle.

two strands run together up the placenta, which is developed basipetally, and separate to pass to their respective ovules in the upper region of the two loculi. The subtending bract and two bracteoles are coherent together to form the familiar wing of the fruit, but this is only slightly adherent to the flower. The perianth receives its vascular supply from the axis below

\footnotetext{
1 E. M. Kershaw, loc. cit., p. 355.
} 
Female Flower of Fuglans regia and a fere allied Genera. 63I

the region of insertion of the carpels. These bundles can be traced up the whole surface of the flower and pass off, three running to each of the four distichously arranged tips of the perianth leaves, as in Fuglans (Textfig. VI. I and 2).

The ovule is bitegumentary, appendicular, and anatropous, and in these

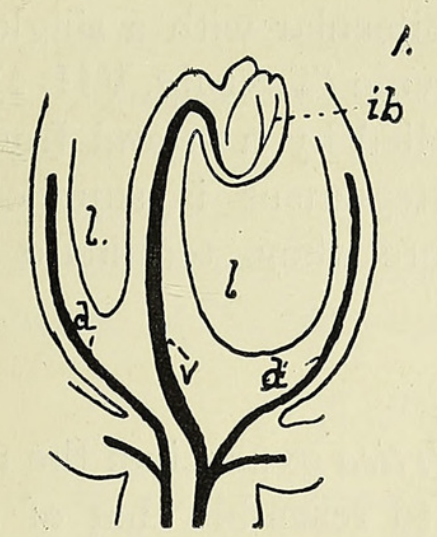

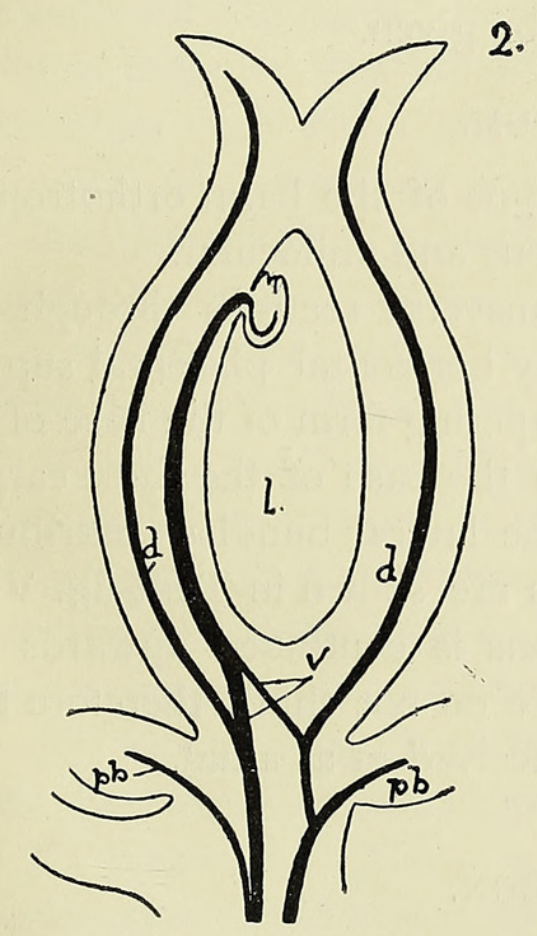

Text-FIG. VII. I and 2. Morus nigra. Flower. Two diagrams from longitudinal sections of the ovaries of different flowers. 1. From a bilocular, uniovular ovary. 2. From a unilocular ovary.

$d=$ dorsal bundles of carpel. $i b=$ integumentary bundle. $l=$ loculus. $p b=$ perianth bundles. $v=$ ventral bundle of carpel or placental bundle.

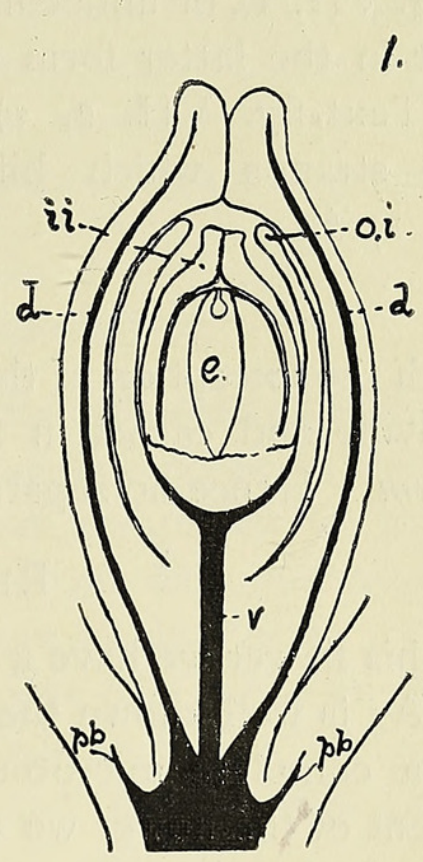

2

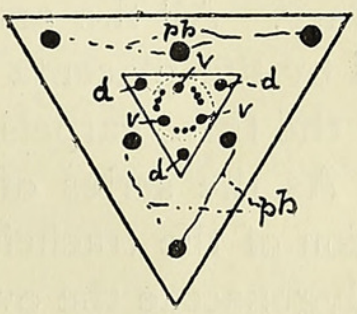

TEXT-FIG. VIII. I and 2. Rheum undula:um. I. Diagram from a longitudinal section of a female flower; the diagram is drawn as if the flower were dimerous. 2. Diagram from a transverse section just below the separation of the perianth. Two whorls of three bundles go to the perianth. The triangular area within these represents the base of the trimerous ovary.

$d=$ dorsal bundles of carpel. $e=$ embryosac. $i i=$ inner integument. $o i=$ outer integument. $p b=$ perianth bundles. $v=$ ventral bundle of carpel or placental bundle.

particulars resembles those of Castanea, Quercus, and Fagus, where, however, the outer and inner integuments are quite free from one another.

In all the Amentiferae so far investigated by us the integuments are free from the nucellus. 
With a view to comparing our results among the Amentiferae with those from nearly allied forms we selected for investigation species of Morus, Urtica, and Rheum.

\section{MORUS NIGRA.}

The ovary here is trimerous or dimerous as in Fuglans. It may be bilocular with one ovule in each loculus, ${ }^{1}$ or bilocular with a single ovule (Text-fig. VII. I), or unilocular also with one ovule (Text-fig. VII. 2). We find that in the latter form the ovule is supplied by a strand from each carpel (Text-fig. VII. 2, v). The outer integument is supplied with vascular strands which bifurcate once before they terminate (Textfig. VII. I, ib).

\section{URTICA DIOICA.}

With the exception of the dimery of the Urtica gynoecium the relation of the ovule and carpel in this genus seems to resemble that of Rheum undulatum. Hence no separate account will be given.

\section{RHEUM UNDULATUM.}

In this flower we have a very advanced type of the basal orthotropous ovule. As is well known the ovary is trimerous and unilocular.

In a complete microtome series of transverse sections through the attachment of the flower we cannot detect any horizontal placental supply. This is undoubtedly to be explained by the tapering form of the base of the superior ovary. All the area enclosed within the base of the three carpels is occupied by the placenta up which runs the lateral bundles contributed equally by the three carpels. These relations are shown in Text-fig. VIII. I and 2. As the series of transverse sections is continued upwards the concentration of the tracheides increases. We do not think therefore that even in Polygonaceae the ovule should be conceived of as axial.

\section{General Discussion.}

\section{Epigyny.}

A consultation of the works of the leading authorities on the morphology of the flower shows a general recognition of the difficulty involved in the use of term 'epigyny'.

Asa Gray ${ }^{2}$ defines epigynous as ' on the ovary or seemingly so'.

$\mathrm{Pax},{ }^{3}$ after defining the inferior ovary as consisting of axis plus floral leaves, continues:- 'Freilich wird immer zu untersuchen sein, ob nicht der

1 Payer, Organogénie de la fleur. Atlas, Plate 61, Fig. 2\%.

2 Asa Gray, Structural Botany, Glossary, p. 409.

${ }^{3}$ Pax, Morphologie der Pflanzen, p. 206. 
Female Flower of Fuglans regia and a few allied Genera. 633

unterständige Fruchtknoten durch Anwachsen der Blüthenhülle entstanden ist.'

In the genera under consideration in this paper we find no trace of that form of epigyny which is brought about by the concavity of the axis and sinking and inclusion of the ovary within it. The female flower of Morus bears a striking resemblance to that of Fuglans, and the Urticales as a whole are brought more into line with the Amentiferae if this fact is borne in mind. The coalescence of the floral leaves is found more or less in such relatively unspecialized families as Nymphaeaceae and Calycanthaceae and hence the so-called epigyny of the Amentiferae need not be regarded as an advanced character. In describing such flowers it would be preferable to avoid the use of the term epigynous.

\section{The Ovule in Angiosperms.}

(a) The ovule is appendicular. The present investigation explains some of the more difficult cases. Eichler ${ }^{1}$ came to the same conclusion, and adds :- Treten mehrere Fruchtblätter zu einem Ovar zusammen, so kann diese Verarmung noch weiter gehen, bis zu dem Extrem, dass von sämmtlichen Carpellen des Ovars nur ein einziges fruchtbar ist und bloss ein einziges Ovulum entwickelt. Je nachdem dies nun höher oder tiefer an der betreffenden Carpellsutur entspringt, erscheint es bald in halber Höhe, bald im Grunde desselben, im letztern Falle oft so tief, dass es den Gipfel der Blüthenaxe zu bilden scheint.'

(b) The ovule is phylogenetically provided with a dual integument. This appears very probable from the investigations of Payer. Such cases as Carpinus afford an interesting link between the less specialized Cupuliferae and the Juglandaceae and Myricaceae which in the reduction of their floral organs seem in advanec of both former families.

(c) Vascular supply of the ovule. We have shown that there are several cases showing a vascular supply similar to that described for Myrica Gale by E. M. Kershaw. ${ }^{2}$ There is no adequate reason to doubt that a wider investigation would reveal numerous instances.

We do not as yet know of a case among Angiosperms with a double vascular supply such as is familiar to us in Lagenostoma Lomaxii.

E. M. Kershaw compares the vascular supply of the ovule of Myrica Gale with the outer series of vascular strands in the ovule Trigonocarpon. There is still some doubt as to the homologies of the complicated integument of the latter. It might therefore be preferable to compare the vascular supply of the outer integument of Carpinus and Morus (and hence probably that of Myrica Gale) with the vascular supply of the outer integument or 'cupule' of Lagenostoma Lomaxii which is far better understood.

1 Eichler, Blüthendiagramme, vol. ii, p. xvi.

2 E. M. Kershaw, loc. cit., p. 357. 


\section{$2 \mathrm{BHL}$ Biodiversity Heritage Library}

Benson, Margaret and Welsford, E. J. 1909. "The morphology of the ovule and female flower of Juglans regia and of a few allied genera." Annals of botany 23, 623-633. https://doi.org/10.1093/oxfordjournals.aob.a089244.

View This Item Online: https://www.biodiversitylibrary.org/item/236540

DOI: https://doi.org/10.1093/oxfordjournals.aob.a089244

Permalink: https://www.biodiversitylibrary.org/partpdf/318979

\section{Holding Institution}

Smithsonian Libraries

\section{Sponsored by}

Biodiversity Heritage Library

\section{Copyright \& Reuse}

Copyright Status: Not in copyright. The BHL knows of no copyright restrictions on this item.

This document was created from content at the Biodiversity Heritage Library, the world's largest open access digital library for biodiversity literature and archives. Visit BHL at https://www.biodiversitylibrary.org. 